\title{
Research on the Influence of Value-added Tax Reform to Enterprise Finance in China
}

GuoShuhua, Dongying Vocational College, Dongying, Shandong, 257091

\begin{abstract}
Our country implemented the standard consumption-based value-added tax in all domestic industry range from 2009. The enterprises' income tax was allowed deduction by income tax from the current when sell a duty.This paper gives the definition and characteristics of the value-added tax at first, and then points out that the value added tax reform is the essential route of tax reform in our country, finally analyses the influence of China's value-added tax reform toenterprise finance in order to provide the reference for related researchers.
\end{abstract}

KEYWORDS:value-added tax reform; enterprise finance

\section{INTRODUCTION}

Value added tax is a type of tax on the appreciation amount obtained by unit or individual in the process of operation. China's value-added tax refers to the tax of value-added amount obtained during the processing and repair services and import goods which were engaged in the sale of goods by the units and individuals within the territory of China.

Value-added tax has the common features of tax and its following own characteristics. (1) The most basic characteristics of value-added tax is the taxation object is only the value of all sales of merchandise, which is also the main characteristics of value-added tax difference between other turnover tax. (2) The value-added tax is relatively single, tax deduction system implementation. The current value added tax rates in all countries of the world are basically no more than three, and the input and output tax shall be the value-added tax invoices deduction. (3) The value added tax general taxation links. This means that the value-added tax can be most of the commodity production and circulation and taxable services included in the taxable scope, as long as the goods or services in a certain production and circulation of existing new increased value need to tax. These features make it different from the traditional turnover tax, which has irreplaceable advantages. The implementation of value-added tax is in favor of tax fairness. The value-added tax in theory can avoid double taxation.

\section{Necessity of Value-added Tax Reform}

Transformation can make our country value-added tax system more reasonable and standardized. The international standard of a tax system is reasonable and normative.One of its important bases for judging whether the tax system is the detection of reflected the "neutral principle of taxation". "The principle of tax neutrality"means value-added tax deduction must be complete. The production type value-added tax is not available, and the consumption type value-added tax deduction to solve the incomplete problem. Transformation is the need of economic structure adjustment, promoting the development of high-tech industry. With the increasingly fierce market competition, enterprises need to improve production efficiency, improve product quality, 
to provide new products needed by the market, these enterprises need to devote sufficient resources to the improvement of the existing production equipment, purchased or internal advanced technology development or technology, but because the deduction does not allow the production of value-added tax, to dispel the enthusiasm of enterprises in this regard, this has restricted the development of high and new technology, delaying the advanced science and technology into productivity rate. Transformation is the need to expand the scope of value-added tax. The reform of the tax system, for the production of goods, wholesale, retail and import link and processing, repair and installation link impose value added tax, while for the construction and installation, transportation, services, transfer of intangible assets or sales of real estate, in accordance with the turnover of a sales tax to form the tax system which has the value-added tax and business tax. The ideal range of value-added tax should include all the creation and realization of value added tax areas in order to ensure the fairness of tax.

\section{Influence of Value-added Tax Reform to Enterprise Finance}

\section{A: Influence on Enterprise Tax}

The purpose of the implementation of consumption type value-added tax in 2009 is to reduce the burden of enterprises and to promote the development of enterprises. In the production of value-added tax, included in fixed assets tax deductions are not allowed from the output value-added tax.The legal value added includes not only the taxpayer to create value and included in the fixed assets cost, makes the enterprise value-added tax is relatively high. Due to the fixed assets can be allowed to be deducted in the value-added tax consumption type value-added tax.Enterprises will inevitably reduce encouraging enterprise fixed assets investment or technological transformation to improve the production and operation conditions. The reform of value-added tax has effect on city maintenance and construction costs and education. City maintenance and construction and education expenses in the current period of additional is enterprise transfer tax as the tax basis of calculation, because of the transformation of value-added tax to reduce the enterprise's value-added tax, so urban construction fees and additional education fee will be reduced. In the production of value-added tax, the initial value of fixed assets confirmation contains the input tax is purchased, and in the consumption of input tax of fixed assets value added tax code allows deduction, not included in the original value of fixed assets. In the two system, the initial fixed asset confirmation value is different, leading to the depreciation of fixed assets of enterprises in various years provision is also different, causing the enterprise income tax payable appear different. The enterprise income tax payables appear different, income tax so production type value-added tax to consumption type value-added tax of enterprises will be increased. From the above on value-added tax, city construction and maintenance costs of the surcharge for education and the change of enterprise income taxin general reduce the overall tax burden of enterprises.

\section{B: Influence on Enterprise Investment Risk}

We analyze the influence of the transformation of value-added tax on fixed assets investment of risk from the perspective of economics.For any investment, income and risk come together. Investors in order to get the benefit, at the same time, also inevitably faced with the risk of. Similarly, the enterprise of 
fixed asset investment, income can be achieved. Therefore, fixed asset investment has risk. The basic relationship between return and risk: benefit and risk corresponding. That is to say, the investment in fixed assets greater risk and the required rate of return is relatively high.On the other hand, the lower rate of return on investment in fixed assets, the risk is relatively small. But, we cannot blindly believe that the greater the risk is, the higher the income is due to the risks and benefits with the basic relationship. In the two kinds of value added tax policy, the fixed asset investment risk is different. Mainly because the fixed assets of enterprises two value-added tax policy of investment costs and depreciation of fixed assets amount is not the same. Therefore, the enterprise of fixed assets investment risk is not the same. By combining economic theory and financial management theory, we analyze the risk and return of investment in fixed assets between different policies as figure shown below. In the following figure, fixed income assets investment risk consumption type value-added tax policy under $\mathrm{I}_{1}$; fixed income assets investment risk production type value-added tax policy for $\mathrm{I}_{2} ; \mathrm{a}$ and $\mathrm{b}$ respectively for the same investment of fixed asset investment undertaken in the added value tax of consumption and production type value-added tax policy of investment risk. As can be seen from the graph, $a$ is less than $b$, that is, consumption of fixed assets investment risk production type value-added tax policy is less than the fixed asset investment risk based value-added tax policy. Therefore, the reform of value-added tax reduces the risk of investment of fixed assets of enterprises.

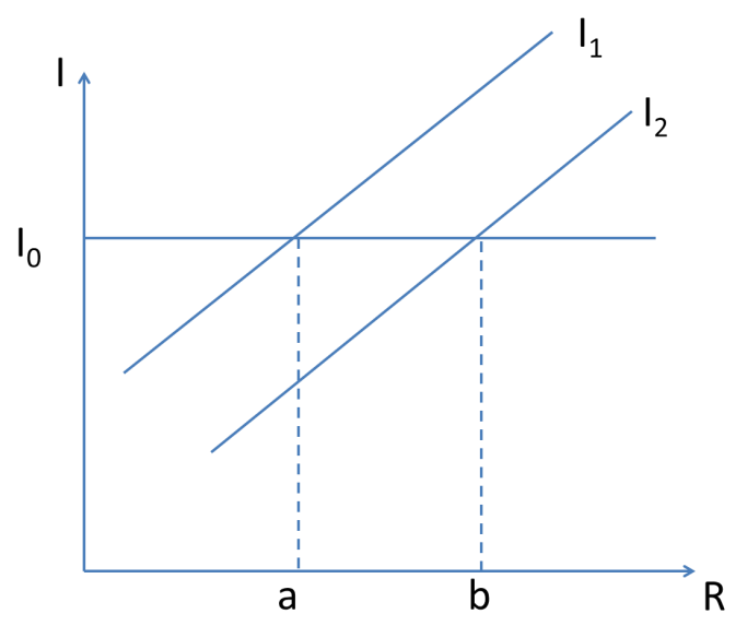

Figure 1Relationship between Fixed Assets Investment and Risk Income

\section{C: Influence on Enterprise Cash Flow}

First of all, from the essence of economic activity, the acquisition of fixed assets belongs to the investment business. It cannot be decomposed into investment and business activities. Secondly, from the accounting perspective of coherence, not as an investment activity in the tax law are not allowed to deduct tax deductible, and in time became the business activities; again the input tax payment, purchase of goods included in the operating activities, not because it can offset, but because in essence is business activities, and part of the cash commodity also belong to the business activities, similarly, fixed assets investment activities cash belongs to itself, the income tax is also belongs to the corresponding investment activities; finally, the sale of a commodity output tax included in the operating activities cash with the commodity itself, the sales of fixed assets fixed assets included in the output tax with investment activities. Therefore, the purchase of fixed assets input tax should also be included in the investment activities with fixed assets. Assume that not considering the effect of the time value of money and business fixed investment under 
the condition of the same amount of outflow, the reform of production type value-added tax to consumption type value-added tax can save the company's current business activities cash and increase the net cash flows of operating activities.

\section{Conclusions}

The core task of the reform of the tax system is to create a fair competitive environment for enterprises and to enhance the competitiveness of enterprises. The value-added tax reform focused on stimulating enterprise investment enthusiasm and improved the efficiency of the enterprise.On one hand,we transformed the production value-added tax to consumption value-added tax to enhance the enterprise market competitiveness; on the other hand, we should alsoconsider graduallyexpanding the scope of value-added tax to include all goods and services. It is the trend of our value-added tax reform.

\section{REFERENCE:}

[1] Sang Guangcheng, Jiao Jianling. The Influence and Countermeasure of Shifting from Paying Sales Tax to Value-added Tax on the Construction Enterprises Finance[J] Construction Economy, 2012, 06

[2] Li Liping. Analysis on the Influences of value-added tax (Value-added Tax) Transformation on Entrepreneurial Finance $[\mathrm{J}]$ Sci-Tech Information Development \& Economy, 2009, 35

[3] Li Zhaofen. Influence of Transformation of Value-Added Tax on Enterprise Financial Statements [J] Nonferrous Metals Design.2012, 03 